\title{
Top Management Team Characteristics, Competitive Environment and Strategy Implementation
}

\author{
Wasike Shadrack Mayende ${ }^{1} \&$ Owino Odhiambo Joseph ${ }^{1}$ \\ ${ }^{1}$ Department of Business Administration, School of Business, University of Nairobi, Kenya \\ Correspondence: Owino Odhiambo Joseph, Department of Business Administration, University of Nairobi, P.O. \\ Box 30197, 00100 Nairobi, Kenya. E-mail: jowino@uonbi.ac.ke
}

Received: April 17, 2020

Accepted: May 12, 2020

Online Published: June 9, 2020

doi:10.5539/ijbm.v15n7p147

URL: https://doi.org/10.5539/ijbm.v15n7p147

\begin{abstract}
Competing favorably in the market requires finding a perfect fit between a firm's resources and the business environment. Strategy is the stewardship by top management that aligns organizational resources and capabilities to the environment with the ultimate goal of achieving superior and sustainable performance. The current study was designed to determine the influence of competitive environment on the relationship between top management team characteristics and strategy implementation. The study adopted the descriptive cross-sectional survey design. Data was obtained by administering structured questionnaire mailed to top managers in tea factory companies in Kenya. The moderation test was carried out using the product term of the standardized scores for top management team characteristics and competitive environment respectively. Data was processed through regression analysis. While we demonstrate that top management team characteristics had significant influence on strategy implementation, the results of moderation tests were not statistically significant. Consequently, our hypothesized moderating influence of competitive environment on the relationship between top management team characteristics and strategy implementation was not supported. Our findings raise theoretical questions on whether competitive environment is more relevant during strategy formulation process or execution stage. We conclude that companies implementing strategy in stable competitive environment have predictable implementation of planned strategy. We further conclude that external insulation from competition by umbrella marketing agency reduces the influence of factors within the competitive environment on the relationship between top management team characteristics and strategy implementation. However, the temporary insulation of the firm from competition exposes it to competitive disadvantage in the event that the marketing agency is destabilized by forces both from within and external to it.
\end{abstract}

Keywords: top management team characteristics, competition, strategy implementation, upper echelons, tea industry

\section{Introduction}

Top management team is a term associated with senior-level managers including Board of Directors, Chief Executive Officers, and other high ranking managers (Guohui \& Eppler, 2008). Top management team is entrusted with the responsibility of navigating the firm to higher performance levels using the firm's resources and capability profiles to exploit opportunities in the business environment. Strategy formulation and implementation are functions performed by top management team to accomplish business performance goals. Strategies are designed by top managers to align organizational goals and operations with the forces in the business environment. Strategy implementation in turn, transforms plans into actions that ultimately influence performance outcomes. Schaap (2006) defined strategy implementation as top management behaviors and actions that transform strategic plan into concrete actions designed to pursue organizational objectives. Bourgeois (1980) concluded that formulation and implementation of strategy are managerial responsibilities aimed at guiding organizational activities. Buul (2010) observed that strategy implementation has become the most important management challenge faced by organizations. Strategy implementation is an organizational process guided by different frameworks depending on top management's perceptions of the business environment. Okumus (2003) suggests that strategy formulation, organizational structure, leadership and organizational behaviour are facilitators of strategy implementation process. One of the strategy implementation frameworks, proposed by Waterman et al. (1980) argues that effective implementation requires addressing 
alignment and interactions among strategy, structure, systems, style, staff, skills and super-ordinate goals.

Hrebiniak (2008) explains that strategy implementation is undertaken through institutionalization and operationalization of strategy. Institutionalization of strategy involves aligning all internal aspects of the organization to the strategy (Waterman, Peters \& Philips, 1980; Machuki et al., 2012). On the other hand, operationalization encompasses splitting the strategy into measurable components by developing a realistic work plan to cover definition of output, setting timelines, budgets, assigning responsibilities to organizational members, allocating resources and handling potential and actual resistance by staff (Alexander, 1985; Okumus, 2003; Buul, 2010). The complexity perspective argues that strategy implementation is an evolving process that requires probabilistic interplay of multiple factors (Okumus, 2003). Bryson and Bromiley (1993) grouped strategy implementation factors in three categories comprising context, process and outcome. They argue that organizational context influences the process of strategy implementation and the resultant outcomes. Bourgeois (1980) argues that effective implementation of strategy is accomplished by aligning organizational resources with conditions in the environment. Consistent with the above arguments, the current study treats competitive environment as the environmental conditions within which an organization operates.

A firm's competitive environment comprises industry forces and actors external to the organization's confines that affect the firm's decisions about products, markets, resource deployment configurations and consequently performance outcomes (Alejandro, Luz \& Esther, 2008). The competitive environment captures the broad conditions that define the structure, conduct and performance of firms within the industry (Porter, 1980; Khan, Ahmed \& Rehman, 2011). Porter (1980) argues that industry structure determines the competitive environment and influences rules of trade in addition to defining how the firm relates with the environment. Further, competition in an industry is rooted in the underlying economic structure and goes beyond the momentary behaviour by competitors. Changes in the competitive environment trigger responses by firms as they engage in finding positions of advantage within the industry, where they can best defend themselves against competitive maneuvers or exploit emerging opportunities (Porter, 1998; Waweru, 2008). Strategy theorists emphasize that organizations must adapt to the environment to survive (Aosa, 1992; Ansoff \& Survillan, 1993). Thus, it is imperative for top management team to predict shifts in the factors that underlie market advantage and consequently respond fast to competitive threats (Waweru, 2008). Porter (1998) postulates that new entrants to an industry may mount insurmountable threat to existing firms by bringing substantial resources with the potential to disrupt existing business models in the industry and attract customers away from competitors.

Top management team oversees strategy implementation and manages the competitive environment with the objective of creating sustained competitive advantage in the industry. Finkelstein and Hambrick (1996) argue that superior organizational performance is a function of complex interactions between internal and external variables. Effective implementation of superior strategy plays the important role of aligning organizational distinctive competencies to opportunities in the competitive environment while at the same time warding off competitive threats. However, strategy implementation is an iterative process because changes in the competitive environment have implications on the implementation process (Nyamwanza \& Mavhiki, 2014). Strategy represents the reflections of top management team mental maps designed to outwit competition (Sterling, 2003) and to sustain the firm's competitive advantage in the long term. Nevertheless, the role of strategy in achieving organizational performance goals can be thwarted by unanticipated competitive response.

The fit between strategy and the firm's competitive environment has attracted immense research interest. Although previous studies have attempted to assess the influence of external environment on the relationship between top management team and performance (Smith, et al., 2001), little focus has been given to testing the role played by competitive environment. Indeed, previous studies are largely premised on assessing forces that either facilitate or impede strategy implementation and the consequential competitive advantage partly attributed to top management team (Okumus, 2003; Ali \& Hadi, 2012). Whereas Tacheva (2007) assessed the moderating influence of competitive environment on the relationship between top management team diversity and performance outcomes, she concludes that top management team is only relevant under turbulent environment. Besides, she cautions that the moderating influence of competitive environment on the relationship between TMT characteristics and organizational outcomes is not straightforward. While several studies have attempted to illuminate the link between strategy, business environment and performance (Ting et al., 2012), little attention has been specifically given to investigating the influence of competitive environment on the relationship between top management team characteristics and strategy implementation. Nevertheless, the industrial organization economics theory argues that industry structure determines nature and intensity of competition influencing the conduct of firms in the industry. Strategy implementation reflects firm conduct in response to industry structure and confounding competitive maneuvers and responses by rival firms. The upper echelons theory on the hand 
holds that characteristics of top managers influence decision patterns of the firm and the resultant performance. Therefore, strategy implementation represents top management perceptions about changes in the competitive environment and the necessary response by the firm to maintain its competitive position or advance its economic interests in the industry. Within these theoretical postulations, our paper is concerned with the role of competitive environment on the relationship between top management team characteristics and strategy implementation. Specifically, our paper addresses the question: 'Does competitive environment moderate the relationship between top management team characteristics and strategy implementation?' The objective of our study is to determine the influence of competitive environment on the relationship between top management team characteristics and strategy implementation.

\section{Literature Review}

The study is premised on the upper echelons theory (Hambrick \& Mason, 1984); the institutional theory (North, 1992); and the industrial organization economics theory (Porter, 1981). The upper echelons theory assumes that it is difficult to objectively predict complex situations, but rather, they are subjectively interpreted (Hambrick, 2007). The theory argues that organizational outcomes are predicted in part by the characteristics of the top management team members. Hambrick and Mason (1984) demonstrate that industry environment can affect the composition of top management team, suggesting an interface between the upper echelon theory and industrial organization economics theory. The industrial organization economics theory is premised on the assumption that industry structure influences the conduct of firms within the industry and consequently performance of the firm. Porter (1981) argues that performance of the firm is directly influenced by an industry's structural attributes. The theory holds that firms in competitive industries can pursue superior performance through differentiation of their products and services, maximizing value to customers, creating high market entry barriers, and reducing elasticity of demand. The institutional theory focuses on the deeper and more resilient aspects of social structure putting into consideration the processes by which such structures become established as authoritative guidelines for social behaviour (North, 1992; Scott 2004). The alternative framework provided by Guohui and Eppler (2008) view strategy implementation from three perspectives namely process, behavioural and hybrid. The process perspective considers strategy implementation as iterative process where environmental threats and strategic responses are major triggers for organizational learning (Lehner, 2004). Harrington (2006) avers that strategy implementation uses organizational systems to convert resources into performance outcomes by exploiting opportunities in the business environment. The behavioural process considers strategy implementation as a managerial action that aligns organizational action with strategic intent. The behavioral perspective treats strategy implementation as organization's deliberate action and relationship with the external environment to accomplish strategic intentions. The hybrid perspective holds that implementation involves reconfiguration of organizational design.

Organizations operating in competitive environment face diverse pressures from within the firm and externally. These forces exert fundamental influence on strategy (Porter, 1980). The traditional Bain/Mason industrial organization paradigm links organization's performance to the nature of the environment in which it competes (Porter, 1981). Mavondo (1999) established that the choice of strategy is constrained by forces within the macro-environment. Whereas the external environment can influence performance of the business, the degree of influence varies depending on the type of strategies chosen by top management team and the effectiveness of implementation of those strategies (Rumelt, 1991). Hrebiniak and Joyce (1985) argue that changes in the environment have implications on strategy. However, strong strategy can influence the competitive environment (Miller, 1998) through its disruptive effects that define products and markets. Alejandro et al. (2008) observed that firms operating in hostile competitive environment perform better when top management team develop an appropriate response strategy that may involve risk taking and aggressive organizational behaviour. The ability of top management team to manage competitive threats and exploit opportunities in the business environment through strategy implementation can improve performance of the firm in the industry. Notably, Noble (1999b) warns that well formulated strategies fail if they are not effectively implemented.

Hrebiniak (2006) observes that strategy implementation is the most challenging phase compared to strategy formulation. Okumus (2003) argues that key strategy implementation factors comprise strategy formulation, environmental volatility, organizational structure, organizational culture and leadership. Other factors include operational planning, resource allocation, communication, people, control and outcomes. The formulation of strategy itself is a process that largely depends on the outcome of environmental analysis. Top management team guides and facilitates analysis of competitive environment and consequently the formulation and implementation of strategy. Top management team support strategy implementation in diverse ways including organizational culture change management, resource deployment, developing supportive systems, communication and control. 
Since top managers play significant roles in strategy implementation, it follows that characteristics of the upper echelon is an important factor within the purview of firm performance. Hambrick and Mason (1984) argue that competitive environment has implications on the characteristics of managers hired in top positions. Further, Tacheva (2007) posits that changes in the competitive environment determine the necessary and desirable characteristics of top management team. For example, Papadakis and Barwise (2002) concluded that firms managed by top management team with higher levels of education are intellectually equipped to effectively analyze the environment and develop an appropriate response strategy.

The uncertainty and complexity associated with competitive environment require top management team members who have the ability to commit the firm to promising opportunities while rejecting those with lower success prospects (Boal \& Hooijberg, 2000). This calls for the commitment by TMTs in ways that promote the generation of creative ideas and choices to solve difficult problems (Ancona \& Nadler, 1989). Nevertheless, top managers must pensively remain alert to changes in the competitive environment by incessant collection and analysis of market intelligence. Machuki and Aosa (2011) observed that changes in the environment may be so fast and diverse that if not well managed may crush response strategies put in place by top management team. Furthermore, changes in the competitive environment require speedy and flexible response by top management team and sometimes radical and ruthless changes within the firm's internal environment. Noble (1999b) argues that changes in the competitive environment may force top management team to undertake adjustments in organizational structure and policy reforms to align the firm with the new strategy.

Strategy implementation process often faces numerous challenges within and outside the organization. Internally, strategy-structure inconsistency breeds resistance, making it difficult to implement strategy. Lack of support by top management, inadequate resources and poor communication frustrate implementation of strategy. Researchers emphasize the importance of communication for effective implementation of strategy (Forman \& Argenti, 2005; Schaap, 2006). Open and supportive communication aids strategy implementation process by facilitating learning and knowledge sharing (Guohui \& Eppler, 2008). Organizational structure becomes a barrier to strategy implementation if it is not aligned to strategy. The strategy formulation process itself may present implementation challenge if it yields stillbirth or vague strategy. Hrebiniak (2006) argues that good implementation cannot correct the defects of a bad strategy or a poor planning effort. Alexander (1985) found that uncontrollable factors emanating from competitive environment can hinder successful implementation of strategies. Villa and Rajwani (2012) undertook a study in Latin America where organizations were constantly challenged by pressures in their competitive environment. They established that the response adopted by each organization was significantly influenced by their manager's perception of factors in the competitive environment, and consequently was prone to producing a particular performance outcome. Basing our arguments on discussed theory and priori evidence highlighted above, we hypothesize that;

Competitive environment has a significant moderating effect on the relationship between top management team characteristics and strategy implementation.

\section{Methodology}

Our study was descriptive in nature and adopted the cross-sectional survey design. The population of the study was Tea Factory Companies registered as members of the Kenya Tea Development Agency. The factory was our unit of analysis. At the time of the study, there were 54 tea factory companies in Kenya (KTDA Ltd, 2015). Tea factory companies were selected for investigation since the tea sub-sector has not received significant research attention despite its important role in Kenya's export earnings. Data was collected by administering structured questionnaire. The questionnaire was developed based on existing measurement scales borrowed from literature (Soroshian et al., 2010; Hambrick \& Mason, 1984). The questionnaire was administered through mail. Follow-ups were done through telephone and physical visits to boost response rate. To control for common source bias, data were collected from four members of the top management team from each organization. Average scores for each organization were computed to constitute the aggregate response.

Cronbach's alpha coefficient was used in the current study to test the reliability of the measurement scales. The results of Cronbach's Alpha coefficient consisting of 0.62 (competitive environment), 0.78 (Top Management Team Characteristics), and 0.933 (strategy implementation) confirmed satisfactory reliability of the research instrument. We subjected the data to diagnostics tests for linear regression assumptions namely linearity, absence of multi-collinearity, absence of autocorrelation and homo-skedasticity. Scatter plots were used to test linearity and homoskedasticity. Kolmogorov-Sminorf test was used to test multivariate normality. Correlation matrix and variance inflation factor (VIF) were used to test for multi-colliearity. Our results revealed that the data met all the conditions for linear regression analysis. We did not observe major outliers in the scatter plots. The variance 
inflation factor results were within acceptable range while the correlation matrix coefficients for TMT characteristics, strategy implementation and competitive environment were low $(<0.4)$. Consequently, we proceeded to test our hypothesis by first computing the interaction term between TMT characteristics and competitive environment. We then regressed strategy implementation on TMT characteristics. In the second stage of the analysis, we regressed strategy implementation on competitive environment while controlling for TMT characteristics. In the final stage, we introduced the interaction term to the model while controlling for both TMT characteristics and competitive environment. We inspected the change statistics between models 2 and 3 , p-value of the interaction term and the beta coefficients to judge whether our hypothesis was supported.

\section{Results}

The results in Table 1 demonstrate that TMT characteristics explained $48.4 \%$ of the variation in strategy implementation $\left(\mathrm{R}^{2}=.482\right.$, $\mathrm{p}$-value $\left.\leq 0.05\right)$. However, model 2 reveals that competitive environment did not have significant influence on strategy implementation ( $p$-value $>0.05$ ). In addition, the change in coefficient of determination from model 1 to model 2 is not significant $\left(\Delta R^{2}=0.013\right)$. Model 3 shows that the interaction term is not statistically significant ( $\mathrm{p}$-value $=.562$ ). Furthermore, the change in coefficient of determination between model 2 and 3 is not statistically significant $\left(\Delta \mathrm{R}^{2}=0.004\right)$. Based on the results of the study, our hypothesis was not supported. Therefore, we empirically demonstrate that competitive environment do not significantly moderate the relationship between TMT characteristics and strategy implementation.

Table 1. Regression summary

\begin{tabular}{|c|c|c|c|c|c|c|c|c|c|c|c|c|}
\hline \multicolumn{13}{|c|}{ Model Summary ${ }^{\mathrm{d}}$} \\
\hline \multirow[t]{3}{*}{ Model } & \multirow[t]{3}{*}{$\mathrm{R}$} & \multirow{3}{*}{$\begin{array}{l}\mathrm{R} \\
\text { Square }\end{array}$} & \multirow{3}{*}{$\begin{array}{l}\text { Adjusted } \\
\text { Square }\end{array}$} & \multirow[t]{3}{*}{$\mathrm{R}$} & \multirow{3}{*}{$\begin{array}{l}\text { Std. Error of the } \\
\text { Estimate }\end{array}$} & \multicolumn{6}{|c|}{ Change Statistics } & \multirow[t]{3}{*}{ Durbin-Watson } \\
\hline & & & & & & R Square & $\mathrm{F}$ & df1 & df2 & & $\mathrm{F}$ & \\
\hline & & & & & & Change & \multicolumn{3}{|l|}{ Change } & \multicolumn{2}{|l|}{ Change } & \\
\hline 1 & $.696^{\mathrm{a}}$ & .484 & .474 & & 1.29488 & .484 & 45.104 & 1 & 48 & .000 & & \\
\hline 2 & $.705^{\mathrm{b}}$ & .498 & .476 & & 1.29179 & .013 & 1.230 & 1 & 47 & .273 & & \\
\hline 3 & $.708^{\mathrm{c}}$ & .501 & .469 & & 1.30094 & .004 & .341 & 1 & 46 & .562 & & 1.595 \\
\hline \multicolumn{13}{|c|}{ a. Predictors: (Constant), tmt } \\
\hline \multicolumn{13}{|c|}{ b. Predictors: (Constant), tmt, ce } \\
\hline \multicolumn{13}{|c|}{ c. Predictors: (Constant), tmt, ce, interactterm of tmt and competitive environment } \\
\hline \multicolumn{13}{|c|}{ d. Dependent Variable: si } \\
\hline
\end{tabular}

Table 2 presents the results of analysis of variance for the tests of moderating influence of competitive environment on the relationship between top management team characteristics and strategy implementation. Inspection of the results show that the model depicting direct relationship between top management team characteristics on strategy implementation is significant and robust $(F=45.104$, $p$-value $\leq 0.05)$. In model 2, we observe that the value of $\mathrm{F}$ statistics declines when we introduce competitive environment to the regression model $(F=23.275)$. In the third model, the strength of $F$ statistics declines further when we introduce the interaction term to the regression model $(\mathrm{F}=15.413)$.

Table 2. Analysis of variance

\begin{tabular}{|c|c|c|c|c|c|c|}
\hline \multicolumn{7}{|c|}{ ANOVA $^{\mathrm{a}}$} \\
\hline Model & & Sum of Squares & df & Mean Square & $\mathrm{F}$ & Sig. \\
\hline \multirow[t]{3}{*}{1} & Regression & 75.627 & 1 & 75.627 & 45.104 & $.000^{\mathrm{b}}$ \\
\hline & Residual & 80.482 & 48 & 1.677 & & \\
\hline & Total & 156.109 & 49 & & & \\
\hline \multirow[t]{3}{*}{2} & Regression & 77.679 & 2 & 38.840 & 23.275 & $.000^{\mathrm{c}}$ \\
\hline & Residual & 78.430 & 47 & 1.669 & & \\
\hline & Total & 156.109 & 49 & & & \\
\hline \multirow[t]{3}{*}{3} & Regression & 78.257 & 3 & 26.086 & 15.413 & $.000^{\mathrm{d}}$ \\
\hline & Residual & 77.852 & 46 & 1.692 & & \\
\hline & Total & 156.109 & 49 & & & \\
\hline $\begin{array}{l}\text { a. Deper } \\
\text { b. Predi } \\
\text { c. Predi } \\
\text { d. Predi }\end{array}$ & $\begin{array}{l}\text { ident Variabl } \\
\text { tors: (Consta } \\
\text { tors: (Consta } \\
\text { ctors: (Consta }\end{array}$ & ractterm of tm & & & & \\
\hline
\end{tabular}


Table 3 presents results of regression coefficients for the test of moderating influence of competitive environment on the relationship between top management team characteristics and strategy implementation. The results demonstrate that top management team characteristics has significant influence on strategy implementation (Std. Beta $=0.696, \mathrm{t}=6.716$, $\mathrm{p}$-value $\leq 0.05$ ). We observe that in model 2, regression coefficient is not statistically significant. The $\mathrm{t}$ statistics for competitive environment in model 2 is relatively low $(\mathrm{t}=$ -1.109). Further, the interaction term did not yield statistically significant results $(\mathrm{t}=0.584, \mathrm{p}$-value $>0.05)$. Consequently, we demonstrate that competitive environment does not moderate the relationship between top management team characteristics and strategy implementation.

Table 3. Regression coefficients

\begin{tabular}{|c|c|c|c|c|c|c|}
\hline \multicolumn{7}{|c|}{ Coefficients $^{\mathrm{a}}$} \\
\hline \multicolumn{2}{|c|}{ Model } & \multicolumn{2}{|c|}{ Unstandardized Coefficients } & \multirow{2}{*}{$\begin{array}{l}\text { Standardized } \\
\text { Coefficients } \\
\text { Beta } \\
\end{array}$} & & \multirow[t]{2}{*}{ Sig. } \\
\hline & & & & & & \\
\hline \multirow[t]{2}{*}{1} & (Constant) & $\begin{array}{l}\mathrm{B} \\
.704\end{array}$ & $\frac{\text { Std. Error }}{2.903}$ & & .243 & .809 \\
\hline & tmt & 1.037 & .154 & .696 & 6.716 & .000 \\
\hline \multirow[t]{3}{*}{2} & (Constant) & 3.064 & 3.593 & & .853 & .398 \\
\hline & tmt & 1.032 & .154 & .693 & 6.696 & .000 \\
\hline & ce & -.148 & .133 & -.115 & -1.109 & .273 \\
\hline \multirow[t]{4}{*}{3} & (Constant) & 21.472 & 31.725 & & .677 & .502 \\
\hline & tmt & .036 & 1.712 & .024 & .021 & .983 \\
\hline & ce & -1.368 & 2.093 & -1.061 & -.653 & .517 \\
\hline & $\begin{array}{l}\text { interactterm of tmt and } \\
\text { competitive } \\
\text { environment }\end{array}$ & .066 & .113 & 1.144 & .584 & .562 \\
\hline
\end{tabular}

a. Dependent Variable: si

\section{Discussion}

The effectiveness of strategy is premised on its adaptability to market dynamics and competition in the industry. Competitive environment in the industry influences the development of organizational capabilities, the selection of distinctive competencies and consequently the choice of strategy (Mavondo, 1999). Hence, industry competition is associated with the design of strategy to align the firm to the business environment (Oyewobi, Windapo \& Rotimi, 2013) with focus on improving the firm's competitive advantage in the market. Therefore, performance of the firm depends on competitive environment, choice of strategy and effectiveness of its implementation (Lenz, 1981). Although the influence of industry competition on the success rate of strategy implementation is well documented in conceptual literature, little empirical investigation has been undertaken to adduce the influence of competitive environment on the relationship between TMT characteristics and strategy implementation. Papadakis et al. (1998) observe that there is little empirical evidence on the link between TMT characteristics and strategy implementation. On the basis of limited empirical evidence, testing the role played by competitive environment on the link between TMT characteristics and strategy implementation was imperative. Our study was designed to establish whether competitive environment moderates the relationship between top management team characteristics and strategy implementation.

The results of the study did not find statistically significant evidence supporting the moderating influence of competitive environment on the relationship between TMT characteristics and strategy implementation. Our findings are consistent with Mavondo (1999) who established that the environment external to the business had little effect on strategy. However, our results are inconsistent with arguments put forward by various scholars that draw closer link between competitive environment and implementation of strategy. For instance, Wu, Chou and $\mathrm{Wu}$ (2004) argue that business firms operating in competitive environment need to be swift and adaptable to competitive maneuvers to remain relevant and successful. Further, they contend that strategy must be corrected to fit the dynamic competitive situation. Drawing from these arguments, our results raise more questions than answers taking into consideration theoretical assertions of firm behaviour in competitive environment. The five forces model (Porter, 1980) presupposes that firms position themselves in ways that enable them to create competitive advantage in the market. In doing so, firms are expected to monitor and respond either proactively or 
reactively to rival's maneuvers. Under the commander model of strategy implementation, top management utilizes competitive intelligence in the allocation of resources to accomplish objectives of the firm (Bourgeois \& Brodwin, 1984). Therefore, the value of the strategy is pegged on the ability of top management team to reduce information asymmetry by obtaining timely and reliable information about competition and the firm's capability to deal effectively with market dependent issues. The firm's competitive environment determines strategic opportunities and the return prospects of strategy implementation (Barney, 1986). Therefore, reactive responses by competitors may influence the firm's approach to implementation of its strategy. Consequently, it would be expected that competitive forces significantly influence implementation of strategy. In support of this view, Al-Ghamdi (1998) argues that uncontrollable factors in the external environment have adverse impact on strategy implementation.

We interpret our findings in three different possibilities. First, we visualize our results within the framework of industrial organization economics theory, where strategy is assumed to follow directly from the industry's structural attributes (Barney, 1986). Under this perspective, the competitive environment impacts on choice of strategy at the formulation stage, but it has little influence on the implementation of strategy particularly where top management team is inflexible to make adjustments necessary to cope with changes in the environment. Incremental changes during strategy implementation are based on the strategic culture of the firm, top management perceptions of competitors and organizational attitude towards its success chances in the market. Organizations guided by the planned strategy approach follow structured strategy management processes during strategy formulation and implementation stages. Environmental analysis is a key process at the strategy formulation stage. Top managers of the organization ensure that a thorough analysis of the competitive environment precedes the crafting of strategy. Exhaustive analysis of the competitive environment is inescapable task for firms concerned with matching its capabilities with opportunities presented in the environment. Organizations acquire or develop distinctive competencies necessary for adapting to the competitive environment and enhancing smooth implementation of strategy. Therefore, competitive environment influences the development of organizational capabilities and the choice of strategy pursued by top management in an organization (Rumelt, 1991). We consider our results to imply once strategy choice is made, its implementation remains relatively stable and proceeds as planned on condition that structure is aligned to strategy and the necessary resources deployed to support smooth implementation.

Our second interpretation of the lack of significant influence of competitive environment on the relationship between TMT characteristics and strategy implementation is based on environmental stability. We take the view that tea factory companies in the Kenyan context, operate in relatively stable competitive environment. The companies studied obtain market intelligence from the one common source, the Kenya Tea Development Agency (KTDA). Consequently, the problem of information asymmetry does not arise. Hence, the perceived competitive rivalry among firms is whittled by equal access to market intelligence. The influence of competitive environment on strategy implementation makes sense on condition that there is volatility in the operating environment. Mason (2007) argues that in stable competitive environment, changes are few and predictable. Therefore, stable competitive environment may have minimal effect on the relationship between top management team characteristics and strategy implementation. A third explanation of our results depicting lack of moderating effect of competitive environment on the relationship between top management team characteristics and strategy implementation stem from possible insulation of tea factory companies by the KTDA marketing agency. The products from tea factory companies benefit from marketing services by KTDA Llimited. The marketing agency insulates tea factory companies by eliminating the liabilities of management inefficiencies and size through oversight management support and marketing services. Furthermore, the marketing agency wields considerable influence in the industry and has the muscle to lobby the government to formulate policies that protect the economic and strategic interests of tea factory companies. Hence, management and marketing services offered by KTDA build capabilities of individual companies and collectively create competitive advantage for tea factory companies in terms of economies of scale; reduced costs of research and marketing; increased bargaining power, and product quality control. Under these protective conditions, the intensity of industry competition is flattened. Hence, competitive environment may have little effect on implementation of planned strategy.

\section{Conclusion}

The objective of the study was to establish the moderating influence of competitive environment on the relationship between top management team characteristics and strategy implementation. The study was guided by the industrial organization economics theory, upper echelons theory and institutional theory. A descriptive cross-sectional survey of Tea Factory Companies in Kenya was carried out and hypothesis tested through linear 
regression analysis. The results of the study demonstrated that the hypothesis was not statistically significant. The results were a pointer to the negligible influence of competitive environment on implementation of planned strategy in industries operating in stable competitive environment. The results support the postulations of the upper echelons theory which assigns top management team characteristics the central role in implementation of strategy. Our results support behavioural process perspective that views strategy implementation as top management deliberate action in managing the relationship between the firm and its environment. Under this alternative theoretical framework, the organizational deliberate action is manifested at the strategy formulation stage wherein, implementation is a planned rollout of the chosen strategy.

From the results of our study, two conclusions were arrived at. First, it was concluded that companies operating in stable competitive environment implement strategy with highly predictable outcomes. Tea industry is characterized by dual structure whereby on the one hand, there are large private tea estates and on the other hand, small and medium scale tea factory companies operating under one large management and marketing agency supported by the government. The umbrella management agency dismantles structural disadvantages that otherwise would have been borne by tea factory companies independently. As a result, the conduct of the industry is determined by few and large market players. This delivers shared competitive advantage to each of the tea factory companies making their strategies implementable on condition that each firm acquires and develops capabilities and competencies to support the strategy implementation. Top management team acquires, configures and deploys resources necessary for strategy implementation. Therefore, competitive environment may affect top management's influence on strategy implementation where the conditions in the industry are dynamic, erratic and unpredictable. Secondly, we conclude that organizations that enjoy temporary insulation from competition by external umbrella marketing agency are not exposed to threats from competitive environment during strategy implementation on condition that the agency itself is effective, competent and serves its members equally without undue advantage to some members. However, in the long-term, the insulation by the agency may expose individual firms to competitive disadvantages particularly where policy changes dismantle or weaken the marketing agency. Although tea factory companies enjoy protection derived from the competence and strength of the marketing agency, they equally may suffer from weaknesses and limitations by the agency that change from time to time based on the internal environment and external pressure. The insulation from external competition builds artificial market advantage largely dependent on the management of the umbrella marketing agency. Therefore, any destabilizing force on the part of the agency takes away market advantages presumably enjoyed by tea factory companies. When this happens, the competitive environment may significantly influence the relationship between top management team characteristics and strategy implementation across the firms in the industry.

\section{Limitations of the Study}

The study was descriptive cross-sectional survey. Whereas attempts were made to improve reliability and validity of the results, the study is not without limitations. First, the population of the study was limited to tea factory companies that were members of an umbrella marketing agency (Kenya Tea Development Agency). Therefore, the scope of our sampling was limited and does not reflect all companies in the tea industry. Secondly, our study was cross-sectional survey using structured questionnaire. Our method of study limits testing for causality. Our research design is limited in the sense that we did not capture detailed explanations from respondents and their own interpretation of the competitive environment. Moreover, strategy implementation is a process that may be studied better using longitudinal research design. Although our results sheds some light on the lack of influence of competitive environment on strategy implementation, we do not completely guarantee this evidence considering that our data were snapshot based on respondents' reflections of top management characteristics, competitive environment and strategy implementation.

\section{References}

Alejandro, E. S., Luz, S. P., \& Esther, S. P. (2008). Moderating influences on the firm's strategic orientation-performance relationship. International Small Business Journal, 26(4), 463-489.

Alexander, L. D. (1985). Successfully implementing strategic decisions. Long Range Planning, 18, 91-97. https://doi.org/10.1016/0024-6301(85)90161-X

Al-Ghamdi, S. M. (1998). Obstacles to successful implementation of strategic decisions. A British experience. European Business Review, 98(6), 322-327. https://doi.org/10.1108/09555349810241590

Ali, M., \& Hadi, A. (2012). Surveying and identifying the factors affecting successful implementation of business strategies in companies of Fars province industrial towns (Case study: companies of food industries). International Journal of Business and Social Science, 3(1), 265-272. 
Ancona, D., \& Nardler, D. A. (1989). Top hats and executive tales. Sloan Management Review, 31(1), 19-28.

Ansoff, H. I., \& Sullivan, P. A. (1993). Optimizing profitability in turbulent environments: A formula for strategic success. Long Range Planning, 26, 11-23.

Aosa, E. (1992). An empirical investigation of aspects of strategy formulation and implementation within large private manufacturing companies in Kenya Unpublished Doctoral Dissertation. University of Strathclyde, Glasgow, Scotland.

Barney, B. J. (1986). Types of competition and theory of strategy: Toward an integrative framework. The Academy of Management Review, 11(4), 791-800.

Barney, B. J. (1991). Firms resources and sustainable competitive advantage. Journal of Management, 1(17), 99-120.

Boal, K. B., \& Hooijberg, R. J. (2000). Strategic leadership research: Moving on. Yearly review of leadership. A special issue of the leadership quarterly, 11, 515-550.

Bourgeois III, L. J. (1980). Strategy and Environment: A Conceptual Integration. The Academy of Management Review, 5(1), 25-39

Bourgeois III, L. J., \& Brodwin, R. D. (1984). Strategic implementation: Five approaches to an elusive phenomenon. Strategic Management Journal, 5(3), 241-264. https://doi.org/ 10.1002/smj.4250050305

Bryson, J., \& Bromiley, P. (1993). Critical factors affecting the planning and implementation of major projects. Strategic Management Journal, 14(2), 319-37. https://doi.org/10.1002/smj.4250140502

Buul, M. V. (2010). Successful strategy implementation. A job for the internal auditor? Executive master of international auditing, Amsterdam Business School, University of Amsterdam.

Feurer, R., \& Chaharbaghi, K. (1995). Researching strategy formulation and implementation in dynamic environments. Benchmarking for Quality Management \& Technology, 2(4), 15-26. https://doi.org/10.1108/14635779510102829

Finkelstein, S., \& Hambrick, D. C. (1996). Strategic leadership: Top executives and their effect on organizations. St. Paul MN West Publishing.

Forman, J., \& Argenti, P. A. (2005). How corporate communication influences strategy implementation, reputation and the corporate brand: An exploratory qualitative study. Corporate Reputation Review, 8(3), 245-264.

Guohui, L. Y., \& Eppler, J. M. (2008). Making strategy work: A literature review on the factors influencing strategy implementation. ICA Working Paper 2/2008

Hambrick, D. C. (2007). Upper echelons theory: An update. Academy of Management Review, 32(2), 334-343.

Hambrick, D. C., \& Mason, P. A. (1984). Upper echelons: The organizations a reflection of its top managers. Academy of Management Review, 9(2), 193-206.

Harrington, R. J. (2006). The moderating effects of size, manager tactics and involvement on strategy implementation in food service. Hospitality Management, 25, 373-397. https://doi.org/10.1016/j.ijhm.2005.02.004

Hrebiniak, L. G. (2005). Making strategy work: Leading effective execution and change. Upper Saddle River, NJ: Wharton School Publishing

Hrebiniak, L. G. (2006). Obstacles to effective strategy implementation. Organizational Dynamics, 35, 12-31. https://doi.org/10.1016/j.orgdyn.2005.12.001

Hrebiniak, L. G. (2008). Making strategy work: Overcoming the obstacles to effective execution. Ivey Business Journal Online, 72(2), 122-142.

Hrebiniak, L. K., \& Joyce, W. F. (1985). Organizational adaptation: Strategic choice and determinism. Administrative Science Quarterly, 30, 336-49.

Khan, N., Ahmed, G., \& Rehman, R. (2011). Crisis in international business environment in India. Journal of Emerging Trends in Economics and Management Sciences, 2(5), 445-449.

Lehner, J. (2004). Strategy implementation tactics as response to organizational, strategic and environmental imperatives. Management Revue, 15, 460-480

Lenz, R. T. (1981). Determinants of organizational performance: An interdisciplinary Review. Strategic 
Management Journal, 2(2), 131-154. https://doi.org/10.1002/smj.4250020204

Machuki, V. N., \& Aosa, E. (2011). The influence of external environment on the performance of publicly quoted companies in Kenya. Business Administration and Management Journal, 1(7), 205-218.

Machuki, V. N., Aosa, E., \& Letting, N. K. (2012). Firm level institutions and performance of publicly quoted companies in Kenya. International Journal of Humanities and Social Science, 2(21), 298-312.

Mason, R. B. (2007). The external environment's effect on management and strategy. A Complexity Theory Approach, 15(1), 10-28. https://doi.org/10.1108/00251740710718935

Mavondo, T. F. (1999). Environment and strategy as antecedents for marketing effectiveness and organizational performance. Journal of Strategic Marketing, 7(4), 237-250. https://doi.org/10.1080/096525499346350

Miller, C. C., Linda, M. B., \& Glick, A. H. (1998). Cognitive diversity among upper echelon executives: implications for strategic decision procedures. Strategic Management Journal, 19, 39-58. https://doi.org/10.1002/(SICI)1097-0266(199801)19:1<39::AID- SMJ932>3.0.CO;2-A

Miller, D. (1988). Relating Porter's business strategies to environment and structure: Analysis and performance implications. Academy of Management Journal, 31(2), 280-309. https://doi.org/10.5465/256549

Noble, C. H. (1999b). The electic roots of strategy implementation research. Journal of Business Research, 45 , 119-134. https://doi.org/10.1016/S0148-2963(97)00231-2

North, D. (1992). Institutions and economic theory, American Economics, 36(1), 3-7.

Nyamwanza, T., \& Mavhiki, S. (2014). Strategy implementation of framework used by SMEs in Zimbabwe. Journal of Business and Management, 3(2), 1-16. https://doi.org/10.12735/jbm.v3i2p01

Okumus, F. (2003). A framework to implement strategies in organizations. Management Decision, 41(9), 871-882. http://dx.doi.org/10.1108/00251740310499555

Oyewobi, L. O., Windapo, A. O., \& Rotimi, J. O. B. (2013). The effects of business environment on corporate strategies and performance of construction organizations. Association of Researches in construction Management, 691-701.

Papadakis, V. M., Lioukas, S., \& Chambers, D. (1998). Strategic decision making processes: The role of management and context. Strategic Management Journal, (19), 115-147. https://doi.org/10.5465/ambpp.2003.13793257

Porter, M. E. (1980). Competitive strategy. Techniques of analyzing industries and competitors. New York: Free Press.

Porter, M. E. (1981). The contributions of industrial organization to strategic management. The Academy of Management Review, 609-620. https://doi.org/10.2307/257639

Porter, M. E. (1998). Competitive Strategy. Techniques of analyzing industries and competitors. New York: Free Press.

Rumelt, R. P. (1991). How much does industry matter? Strategic Management Journal, 12, 167-85. https://doi.org/abs/10.1002/smj.4250120302

Schaap, J. L. (2006). Toward strategy implementation success: An empirical study of the role of senior-level leaders in the Nevada Gaming Industry. UNLV Gaming Research \& Review Journal, 10(2), 13-37.

Scott, W. R. (2004). Institutional theory. An Encyclopedia of social theory. Thousand Oaks, CA: Sage.

Smith, G. K., Ferrier, J. W., \& Ndofor, H. (2001). Competitive dynamics research: Critique and future directions. Handbook of Strategic Management. London: Blackwell Publishers

Sterling, J. (2003). Translating strategy into effective implementation: dispelling the myths and highlighting what works. Strategy \& Leadership, 31(3), 27-34. https://doi.org/10.1108/10878570310472737

Tacheva, S. (2007). Top management team diversity: A multilevel exploration of antecedents and consequences. Unpublished $\mathrm{PhD}$ Thesis, University of St. Gallen, Graduate school of business administration, economics, law and social sciences (HSG), Bulgaria.

Villa, M. A., \& Rajwani, T. (2013). The mirror trap. Do managerial perceptions influence organizational responses to crises? Academia. Revista Latinoamericana de Administración, 26(1), 170-188. https://doi.org/10.1108/ARLA-05-2013-0044

Waterman, R. H., Peters, T. J., \& Philips, J. R. (1980). Structure is not organization. Business Horizons, 23(3), 
14-26. https://doi.org/ 10.1016/0007-6813(80)90027-0

Waweru, M. A. S. (2008). Competitive strategy implementation and its effects on performance in large private sector firms in Kenya. Unpublished PhD Thesis, University of Nairobi.

Wu, Y.W., Chou, H.C. \& Wu, J.Y. (2004). A study of strategy implementation as expressed through Sun Tzu's principles of war. Industrial Management \& Data Systems, 104(5), 396-408. https://doi.org/10.1108/02635570410537480

\section{Copyrights}

Copyright for this article is retained by the author(s), with first publication rights granted to the journal.

This is an open-access article distributed under the terms and conditions of the Creative Commons Attribution license (http://creativecommons.org/licenses/by/4.0/). 